medRxiv preprint doi: https://doi.org/10.1101/2021.12.23.21268321; this version posted December 25, 2021. The copyright holder for this

\title{
Influenza A H1N1-mediated pre-existing immunity to SARS-CoV-2 predicts COVID-19 outbreak dynamics
}

Nerea Martín Almazán ${ }^{1,2,3 *}$, Afsar Rahbar 1,2*†, Marcus Carlsson ${ }^{4}$, Tove Hoffman ${ }^{5}$, Linda Mats Ohlin ${ }^{8}$, Mariusz Sacharczuk ${ }^{9,10}$, Piotr Religa ${ }^{1,2,10}$, Stefan Amér ${ }^{11}$, Christian Molnár ${ }^{11,12}$, Åke Lundkvist $^{5}$, Andres Susrud ${ }^{13}$, Birger Sörensen ${ }^{13}$, Cecilia Söderberg-Nauclér ${ }^{1,2, \dagger}$

${ }^{1}$ Department of Medicine, Unit for Microbial Pathogenesis, Karolinska Institutet, Stockholm, Sweden. ${ }^{2}$ Department of Neurology, Karolinska University Hospital, Stockholm, Sweden.

${ }^{3}$ Department of Laboratory Medicine, Division of Pathology, Karolinska Institutet, Stockholm, Sweden. ${ }^{4}$ Centre for the Mathematical Sciences, Lund University. ${ }^{5}$ Zoonosis Science Center (ZSC), Department of Medical Biochemistry and Microbiology (IMBIM), Uppsala University, Uppsala, Sweden. ${ }^{6}$ Division of Clinical Microbiology, Department of Labortory Medicine, Karolinska Institutet, Stockholm, Sweden. ${ }^{7}$ Department of Clinical Microbiology, Karolinska

University Hospital, Stockholm, Sweden. ${ }^{8}$ Department of Immunotechnology and SciLifeLab Human Antibody Therapeutics Infrastructure Unit, Lund University, Lund, Sweden. ${ }^{9}$ Faculty of Pharmacy with the Laboratory Medicine Division, Department of Pharmacodynamics, Medical University of Warsaw, Centre for Preclinical Research and Technology, Banacha 1B, Warsaw, Poland. ${ }^{10}$ Department of Experimental Genomics, Institute of Genetics and Animal

Biotechnology, Polish Academy of Sciences, Postępu 36A, Jastrzebiec, Poland. ${ }^{11}$ Familjeläkarna Saltsjöbaden, Saltsjöbaden, Sweden. ${ }^{12}$ Department of Neurobiology, Care Sciences and Society, NVS, Karolinska Institutet, Stockholm, Sweden. ${ }^{13}$ Immunor AS, Oslo, Norway.

*These authors contributed equally to this work.

†Corresponding authors: Email: cecilia.naucler@ki.se, afsar.rahbar@ki.se 
medRxiv preprint doi: https://doi.org/10.1101/2021.12.23.21268321; this version posted December 25, 2021. The copyright holder for this preprint (which was not certified by peer review) is the author/funder, who has granted medRxiv a license to display the preprint in perpetuity. All rights reserved. No reuse allowed without permission.

\section{Abstract}

Susceptibility to SARS-CoV-2 infections is highly variable, ranging from asymptomatic and mild infections in most, to deadly outcome in few. Here, we present evidence that antibodies induced by currently circulating influenza A H1N1 (flu) strains cross react with the most critical receptor binding motif of the SARS-CoV-2 spike protein that interacts with the ACE2 receptor. About 58$68 \%$ of blood donors in Stockholm had detectable antibodies to this cross-reactive peptide, NGVEGF, and seasonal flu vaccination trended to enhance binding of inhibitory antibodies to SARS-CoV-2. This peptide also activated CD8 T cells in $20 \%$ of healthy subjects. Eleven additional CD8 T-cell peptides that cross-react with flu and SARS-CoV-2 were identified that potentially protect against SARS-CoV-2 in 40-71\% of individuals, depending on their HLA type.

\section{One-Sentence Summary}

Flu-mediated pre-immunity to SARS-CoV-2 may protect against COVID-19 and likely affects herd immunity thresholds. 
medRxiv preprint doi: https://doi.org/10.1101/2021.12.23.21268321; this version posted December 25, 2021. The copyright holder for this preprint (which was not certified by peer review) is the author/funder, who has granted medRxiv a license to display the preprint in perpetuity. All rights reserved. No reuse allowed without permission.

Although the COVID-19 epidemic was declared a pandemic in March 2020, it is still not fully under control, and emerging mutant strains continue to cause great concern. SARS-CoV-2 is considered a new virus to humans. Therefore, a major impact was expected. Mathematical modeling predicted an infection rate of at least $70 \%$ within a few months, suggesting catastrophic scenarios of collapsed health care systems and high death tolls if strict nonpharmacological mitigation strategies were not implemented (1). However, after the first wave, measured seroprevalence levels were less than $25 \%$ in a majority of hard-hit locations. In Stockholm, Sweden, a seroprevalence of $12 \%$ was reached in September 2020 after the first wave and under less strict nonpharmacological interventions than in most other countries. by the original strain were asymptomatic. Among people with symptomatic infections, $80 \%$ had mild symptoms; $20 \%$ developed severe disease and required hospital care, and 3-5\% were admitted to the intensive care unit $(2,3)$. People over 70 years of age and those with obesity, type II diabetes, or hypertension are at higher risk of severe disease (4), and the impact on some patients, even young previously healthy people, can be disastrous. A possible explanation for differences in susceptibility is pre-existing protective immunity, suggested by the unexpected decline in infections during the first wave of the pandemic. In June 2020, $11 \%$ were estimated to be seropositive for SARS-CoV-2 in Stockholm, yet the decline started in early April, about 1 month after the onset of the first wave, despite limited mitigation strategies that were not well followed by Swedes. From mid-March 2020, high schools and universities were on distance learning, people were expected to work from home and, if possible, avoid public transportation. Frequent hand washing, social distancing, and staying at home if feeling sick were the main recommendations from health authorities and the government. A lock-down was never implemented, elementary and 
medRxiv preprint doi: https://doi.org/10.1101/2021.12.23.21268321; this version posted December 25, 2021. The copyright holder for this

middle schools remained open, and until January 2021, face masks were not recommended, even in the care of vulnerable patients in hospitals.

The decline of cases in larger cities in Sweden continued from April, even though people were no longer following stricter recommendations, which implied some kind of protective immunity. Infection rates on cruise ships also peaked at $\sim 20 \%$, even though many passengers were older than 70 (5). By May 2020, 19.1\% of 2149 staff members at Danderyd's Hospital in Stockholm tested positive for SARS-CoV-2 antibodies (6). Furthermore, rarely more than 15-20\% of household members became infected after diagnosis of a family member with COVID-19 (7). At several elder care homes in Stockholm and Uppsala, about $23 \%$ of personnel rapidly became antibody positive during the first wave (8). In New York, seroprevalence was 23.6\% after the spring of 2020 (9).

We hypothesized that this pattern of declining viral spread and the apparent protection of about $80 \%$ of the population from severe COVID-19 disease is best explained by a pre-existing immunity, which would also contribute to herd immunity thresholds. To test this hypothesis, we used mathematical models to study the effects of factors such as nonpharmacological interventions, age, interactive patterns, mobility, and pre-immunity. It proved impossible to match modeled and real data without incorporating a pre-existing immunity level of $50-60 \%(10,11)$. We therefore set out to identify the source of the pre-immunity.

\section{Flu mediated pre-immunity to SARS-CoV-2}

Pre-immunity to SARS-CoV-2 is most likely mediated by previous infections. Indeed, $40-60 \%$ of healthy blood donors, including those giving blood before SARS-CoV-2 existed, respond to SARS-CoV-2 peptides in vitro (12-15), and pre-existing polymerase-specific $\mathrm{T}$ cells expand, particularly in patients with abortive infections (15). It was suggested that T-cell pre-immunity was caused by common cold coronaviruses (16-18) and could contribute to herd immunity levels 
medRxiv preprint doi: https://doi.org/10.1101/2021.12.23.21268321; this version posted December 25, 2021. The copyright holder for this preprint (which was not certified by peer review) is the author/funder, who has granted medRxiv a license to display the preprint in perpetuity. All rights reserved. No reuse allowed without permission.

(19-21). Hence, in some people, T cells trained to recognize unrelated pathogen peptides may protect against severe COVID-19 through cross-immunity (or molecular mimicry). However, as this virus can be transmitted by aerosols (22), it is unlikely that $\mathrm{T}$ cells protect against infection with SARS-CoV-2 on a population level. Instead, antibody protection is expected to be required.

Neutralizing antibodies to SARS-CoV-2 have been found in pre-pandemic sera (23) and must have been triggered by another pathogen. One report suggested that $44 \%$ of children and $5.7 \%$ of adults have antibodies to common coronaviruses that provided neutralizing activity against SARSCoV-2 (18). This level of pre-immunity would not explain the slow-down of SARS-CoV-2 spread after about $20 \%$ of a population becomes infected. Also, although coronavirus antibody titers are boosted by SARS-CoV-2 infection, these are not considered protective (24). We therefore searched for potential cross-reactivities between SARS-CoV-2 and other pathogens. A BLAST search for cross-reactive protein sequences between SARS-CoV-2 and any other unrelated pathogen identified no homologies of significance. However, a method focusing on small 6-mer peptides to search for cross-reactive epitopes that are optimal for antibody binding identified a peptide in SARS-CoV-2, NGVEGF (Fig. 1A), that is identical to a peptide in the neuraminidase of two strains of influenza A H1N1 (swine flu): Nagasaki/07N005/2008 and Kyoto/07K520/2008. A variant, NGVKGF, was present in 99.3\% of swine flu strains $(n=18,972)$ sequenced after 2008 and in $31.4 \%$ of strains $(n=1467)$ sequenced before 2008 (Table 1).

Remarkably, this peptide was present in the most critical part of the receptor binding motif of the spike protein (amino acids (aa) N481 to F486, Fig. 1A) that interacts with the angiotensin converting enzyme 2 (ACE2) receptor (Fig. 1B) (25). In H1N1, the NGVEGF/NGVKGF peptide is situated in an immunodominant region of the neuraminidase protein (Fig. 1C) and is expected to elicit an antibody response in most people infected with swine flu (26). NGVKGF is present in 
medRxiv preprint doi: https://doi.org/10.1101/2021.12.23.21268321; this version posted December 25, 2021. The copyright holder for this preprint (which was not certified by peer review) is the author/funder, who has granted medRxiv a license to display the preprint in perpetuity. All rights reserved. No reuse allowed without permission.

SARS-CoV-2 variants from Brazil (gamma, P1), South Africa (beta, B.1.351, V 501Y.V2), and New York (iota, B.1.526) that carry an E484K mutation, and concerns have been raised that vaccines are less protective against viruses carrying this mutation (27). In theory, antibodies against the NGVEGF/NGVKGF peptides in swine flu may protect against SARS-CoV-2 by inhibiting cell entry and would not be affected by the E484K mutation; however, they might be affected by E484Q (28) and the new omicron E484A mutation. Swine flu strains containing NGVKGF are currently circulating and are included in seasonal flu vaccines. Thus, antibodies to NGVEGF/NGVKGF developed during a swine flu infection or after a seasonal flu vaccination may protect against SARS-CoV-2 infections.

\section{Receptor binding motif-specific antibodies in COVID-19-negative individuals}

To test the hypothesis that the NGVEGF peptide protect against SARS-CoV-2 infection, we collected plasma/serum samples from 328 healthy persons in September 2020 and analyzed the samples for the presence of IgG-specific antibodies to SARS-CoV-2 spike and to the NGVEGF peptide. Spike-specific antibodies were detected with a multiplex assay in $53(16.2 \%)$ of 328 samples (Figure 1D and E) (29). To detect NGVEGF peptide-specific antibodies, we developed a diagnostic ELISA method. Antibody reactivity to linear NGVEGF-containing peptides was lower than to peptides with a cysteine bridge (with its natural loop structure) or to peptides biotinylated in the C-terminal end of the peptide (data not shown). We therefore chose to use the cysteine loop NGVEGF containing a 11-amino acid SARS-CoV-2 peptide with biotin in the $\mathrm{N}$ terminus for the ELISA method.

Since everyone has been exposed to swine flu, there is no optimal negative control to estimate a cut-off value for positivity. Serum positivity for IgG antibodies to NGVEGF was $73 \%$ at a threshold optical density (OD) value $\geq 0.2$ (Fig. $1 F$ and $G$ ), $68 \%$ at $\mathrm{OD} \geq 0.3$ and $55 \%$ at $\mathrm{OD} \geq 0.4$. 
medRxiv preprint doi: https://doi.org/10.1101/2021.12.23.21268321; this version posted December 25, 2021. The copyright holder for this preprint (which was not certified by peer review) is the author/funder, who has granted medRxiv a license to display the preprint in perpetuity. All rights reserved. No reuse allowed without permission.

Of note, none of 53 COVID-19-positive subjects had high titers of NGVEGF-specific antibodies (OD >1.4, Fig. 1F). Since the prevalence or titers of NGVEGF-specific antibodies did not appear to increase after SARS-CoV-2 infection, we speculate that NGVEGF is more immunogenic when present in neuraminidase (at a highly immunogenic site) than when present in the SARS-CoV-2 spike protein. Flu may also induce a more long-lasting antibody response than SARS-CoV-2. Since the majority of people have some NGVEGF-reactive antibodies, these new insights affect the interpretation of the role of NGVEGF-specific antibodies in SARS CoV-2 infected individuals, especially concerning their protective effects against variant viral strains containing the E484K, E484Q or the new E484A omicron mutation (28).

The NGVEGF/NGVKGF peptide arose in swine flu in 2009 and was subsequently present in $>99 \%$ of H1N1 strains. Therefore, we examined the prevalence of NGVEGF-specific antibodies in patient sera collected before and after 2008 (52 samples from 2011 and 223 from 1996). At an $\mathrm{OD} \geq 0.3,73 \%$ of sera from 2011 and $66 \%$ of sera from 1996 (Fig. 1H and I) contained NGVEGFreactive IgG antibodies, albeit not at the higher OD value ranges $>2.0$ we found in sera from 2020 (Fig. 1F). Since antibody prevalence was also high in serum from 1996, we searched for other peptides that could have elicited an antibody response to NGVEGF in people before swine flu emerged. We identified three peptides-NGVKGF, DGVKGF, and NGIKGF-that were structurally similar to NGVEGF and that may also have contributed to a protective immune response to SARS-CoV-2. NGIKGF was present in $1(<0.01 \%)$ and DGVKGF in $990(67.5 \%)$ of 1467 H1N1 strains (Table 1). NGVEGF was not found in any H1N1 strain sequenced before 2008 (Table 1). After 2008, DGVKGF was present in $107(0.56 \%)$ and NGIKGF in $12(<0.01 \%)$ of 18,972 strains. Thus, both DGVKGF and NGVKGF might have triggered antibody responses mediating cross-protective immunity to SARS-CoV-2. 
medRxiv preprint doi: https://doi.org/10.1101/2021.12.23.21268321; this version posted December 25, 2021. The copyright holder for this

We next established a Luminex Multiplex bead array assay to compare antibody reactivity to 8 NGVEGF or NGVKGF spike peptides (11 or 17 aa in length, table S1). The peptides were synthesized with a cysteine bridge and biotinylated at the $\mathrm{N}$ or $\mathrm{C}$ terminus, respectively. Three SARS-CoV-2 peptides, an adenovirus peptide, and an irrelevant peptide (Neglle1) served as controls. Using this method, we confirmed a variable antibody reactivity to NGVEGF (peptide 3) and NGVKGF (peptide 7) in human sera (Fig. 2A-D). Antibodies did not bind well to the short NGVEGF peptides, but bound better to the longer NGVEGF flu peptides (data not shown). The highest reactivity was to the long NGVKGF peptide biotinylated at the $\mathrm{N}$ terminus (peptide 7) and was found both in COVID-19-positive and -negative individuals (Fig. 2B and D). Sera that contained NGVKGF- or NGVEGF-reactive antibodies rarely recognized the full-length spike protein, which highlights the limitations of different methods used and the difficulty of interpreting the functional potential of antibodies from experimental studies. COVID-19-positive subjects generally had low median absolute deviation (MAD) values to NGVKGF (peptide 7, Fig. 2 E and F), and some did not mount an antibody response to NGVEGF (peptide 3, Fig. 2E). However, several subjects with anamnestic flu and some with known family exposure to SARS-CoV-2 who did not become infected with SARS-CoV-2 had antibodies with high MAD values to NGVKGF (example in Fig. 2G). These antibodies were also prevalent among COVID-19-negative blood donors with unknown SARS-CoV-2 exposure (example in Fig. 2H).

\section{Inhibitory antibodies to SARS-CoV-2 are enhanced after flu vaccination}

As we found that the plasma samples were toxic in a virus neutralization cell culture test (data not shown), we tested the ability of pre-existing antibodies to inhibit binding of the spike protein to the ACE2 receptor in a SARS-CoV-2 surrogate virus neutralization test (Supplemental Information). Plasma samples from only 19 subjects collected before and after vaccination to flu 
medRxiv preprint doi: https://doi.org/10.1101/2021.12.23.21268321; this version posted December 25, 2021. The copyright holder for this

and thereafter to COVID-19 were included in this test, as when ethical permission was granted for the study, almost all flu vaccines had been administered in Sweden and COVID-19 vaccinations were ready to start. We observed some enhanced potential protective SARS-CoV-2 immunity by flu vaccination (VaxigripTetra Quadrivalent Flu vaccine, Sanofi Pasteur) (table S4). Subjects with enhanced by flu vaccination (mean 55\%) and further by COVID-19 vaccination (mean 94\%) (Fig. 3A). Four subjects with suspected flu within the past 2 years had inhibitory antibody activity at levels similar to those after flu vaccination (mean 47\%), which was further enhanced by COVID19 vaccination (72\%) (Fig. 3B). Twelve elderly people (>80 years) only had a minor increase in the inhibitory effect of antibodies after flu vaccination, from $34.3 \%$ before to a mean of $40.2 \%$ after flu vaccination and to $61 \%$ after COVID-19 vaccination (Fig. 3C and table S4); however, for some of them this capacity was still concerningly low (Fig. 3C and table S4). Nine (75\%) had an adequate response to the mRNA BNT162b2 vaccine from Pfizer-BioNTech (mean inhibition 68\%), and three had an insufficient response (mean 39\%) after two vaccine doses (Fig. 3D and table S4), which was also reflected in lower SARS-CoV-2 specific antibody levels. This inhibitory effect was higher in the seven other subjects of various ages, and increased from $41.2 \%$ before to $50.6 \%$ after flu vaccination and to $81.4 \%$ after COVID-19 vaccination (Fig. 3E), and they all had adequate antibody levels to SARS-CoV-2.

\section{Flu-mediated protection to SARS-CoV-2 may vary in different populations}

While antibodies may protect people from becoming infected, cytotoxic $\mathrm{T}$ cells are crucial to resolve life-threatening infections by killing virus-infected cells. In modeling analyses, we found that the NGVEGF peptide can be presented to CD8 T cells by some HLA class I molecules (HLAA*33:01, HLA-A*68:01, HLA-A*31:01, HLA-A*11:01) found in about $22.2 \%$ of Scandinavians 
medRxiv preprint doi: https://doi.org/10.1101/2021.12.23.21268321; this version posted December 25, 2021. The copyright holder for this

(table S2). We confirmed that $\mathrm{B}$ and $\mathrm{T}$ cells from healthy subjects recognize and respond to NGVEGF peptides in vitro and that this reactivity was boosted in some people after seasonal flu vaccination $(n=20)$. The response was highly individual and differed for CD19, CD4, and CD8 $\mathrm{T}$ cells. Flu-vaccinated subjects had significantly more IFN- $\gamma$ producing CD8 $\mathrm{T}$ cells that recognized the NGVEGF peptide (mean increase from $1.1 \%$ to $2.3 \%, p=0.009$ ) and B cells (mean increase from $1.9 \%$ to $3.5 \%, p=0.003$ ); IFN- $\gamma$ producing CD4 T cells reactive to the NGVEGF peptide also trended higher after flu vaccination (mean increase from $1.6 \%$ to $2.0 \%, p=0.0567$, Fig. 3F). Interestingly, 7 of $20(35 \%)$ individuals had a robust increase in the numbers of CD8 T cells reactive to NGVEGF (mean increase $4.3 \%$ ); about $22 \%$ of Scandinavians are expected to have HLA types able to present this peptide efficiently to T cells.

Further screening identified 11 additional influenza H1N1 cross-reactive CD8 T-cell peptides to SARS-CoV-2 (table S3). Modeling implied that they could be presented by HLA types found in about $71 \%$ of people in Scandinavia (mainly HLA-A*02:01 and HLA-A*01:01), but in only $40 \%$ of people worldwide (table S2). Thus, the strength of protective immunity induced by influenza A H1N1 strains may vary around the globe.

Our observations imply that some people who are vaccinated against seasonal flu can increase their immune protection against SARS-CoV-2. Indeed, several epidemiological studies showed that seasonal flu vaccination provides significant protection against COVID-19, hospitalizations, ICU admission, and death (30-33), in the range of the protection level estimated in the present study. In a mouse model, we confirmed that the VaxigripTetra Quadrivalent flu vaccine induced a response to the SARS-CoV-2 NGVEGF peptide; an IgM-specific antibody response to NGVEGF was detected 2 weeks after vaccination (Fig. 3G). A boost with a vaccine containing VaxigripTetra Quadrivalent HA and NA proteins coated with five SARS-CoV-2 peptides (developed for a 
medRxiv preprint doi: https://doi.org/10.1101/2021.12.23.21268321; this version posted December 25, 2021. The copyright holder for this

combined flu/COVID19 peptide vaccine and including NGVEGF) elicited robust IgM and IgG antibody responses to NGVEGF 4 weeks after the second dose (Fig. 3G and H). Thus, a combined vaccine strategy may be advantageous to develop protective and longer-lasting antibodies to the receptor binding motif of spike that interacts with the ACE2 receptor.

\section{that has dampened pandemic spread of the virus}

Evidently, a substantial proportion of the population has antibodies to NGVEGF, and seasonal flu vaccination boosts the immune response to SARS-CoV-2. To further understand whether flumediated cross-reactivity to SARS-CoV-2 might have dampened the epidemic on a population level, we turned to mathematical models. We recently showed that mathematical models provide a good match between modeled and observed data—but only if a protective pre-existing immunity level of 50-65\% is included. A similar percentage of people had NGVEGF-specific antibodies in the present study (55\%-68\%), implying that antibodies in the lower interval (OD 0.2-0.3) may not provide much protection. No other parameter we examined affected the model output in a similar manner $(10,11)$.

Here, we established a simple mathematical method to estimate the pre-immunity level in a population directly from the time series of cases and point estimates of seroprevalence, avoiding more complex models such as SEIR (susceptible, exposed, infective, recovered). We implemented the SEIR-code by Britton et al. (34), of which there are two versions. A simple version takes interactive patterns between different age groups into account (Age SEIR), and the second also considers variations in social activity (Age-Act SEIR) (Fig. 4A). We tested these models on case data from Stockholm, using data from the second wave (Fig. 4A and B), as testing was not reliable 
medRxiv preprint doi: https://doi.org/10.1101/2021.12.23.21268321; this version posted December 25, 2021. The copyright holder for this

during the first wave. Data from the Swedish Public Health Agency allowed for separation of cases by the original versus the alpha strain. The blue curve in Fig. 4 represents cases in the second wave caused by the original strain only, readjusted to account for underreporting of cases. Based on data from the Swedish Public Health Agency, seroprevalence was 10\% in Stockholm at the start of the second wave (early September 2020) and rose to $22.6 \%$ in mid-February 2021, between the second and third waves $(10,11)$. These findings are consistent with the seroprevalence estimated from our serology data: 16.2\% $(n=328)$ in late September 2020 and 21.1\% $(n=450)$ in late February 2021. When we attempted to fit the curve of cases with either SEIR model using an immunity level of $10 \%$, the curves are nowhere near reality (Fig. 4A), indicating that substantial updates in people's behavior would have caused the demise of the second wave, but this seems highly unlikely (see $(10,11)$ for a fuller discussion of this topic). However, an almost perfect fit resulted when we used pre-immunity levels of $60 \%$ for Age-SEIR and 50\% for Age-Act SEIR, which corresponds to a pre-pandemic immunity protective level of 60-70\% (Fig. 4B). This level correlates remarkably well with the measured seroprevalence of NGVEGF-specific antibodies in people in Stockholm (55-68\%) and with the modeled HLA class I-mediated protective T-cell immunity levels for a Scandinavian population (estimated to be $71 \%$ according to expected HLA types in the population). No other parameter we examined affected the model output in a similar manner. Thus, it was not possible to match modeled data to actual case data without taking a substantial protective pre-existing immunity into consideration (Fig. 4A and B). These findings also imply that, in the absence of pre-immunity, $\mathrm{R}_{0}$ would have been substantially higher than current estimates have predicted. Our method estimates that $\mathrm{R}_{0}$ is around 5 in the hypothetical absence of pre-immunity. With an $\mathrm{R}_{0}$ of 5 and a pre-immunity of $62 \%$, the number of secondary infections caused by one infected individual will be $5(1-0.62)=1.9$, which is similar to estimates from March 2020 . 
medRxiv preprint doi: https://doi.org/10.1101/2021.12.23.21268321; this version posted December 25, 2021. The copyright holder for this

We next ran the code on case data for India, which we expected to have a lower pre-immunity protection, as a result of different HLA types than in Scandinavians (40\% and expected from Stockholm data to be effective at around 20-30\% in first wave and 10-20\% for India's delta wave). We used seroprevalence data released by the Indian Council of Medical Research; 7\% in August/September 2020, 24\% around January 1, 2021, and 67\% in June/July 2021 (https://indianexpress.com/article/explained/explained-icmr-covid-fourth-serosurvey-findings7413949/). Using a 25\% pre-immunity against the original strain and a $10 \%$ pre-immunity for the delta variant, and assuming an antibody half-life of 16 months after natural infection (35), the model fit the observed case data well, implying that pre-immunity protection, as expected, was lower for India than Stockholm.

Our modeling data support the hypothesis that pre-existing immunity to influenza A H1N1 strains protected a large set of people from SARS-CoV-2 infection or severe COVID-19. Such immunity is not expected to provide sterilizing immunity to SARS-CoV-2. Rather, it acts as a brake on epidemic spread, as a higher viral dose is needed to infect someone who has a substantial level of flu-mediated pre-immunity under current nonpharmacological interventions. People with high titers of antibodies and higher levels of T cells that cross react with flu and SARS-CoV-2 are likely better protected against SARS-CoV-2, perhaps especially after a recent H1N1 infection or seasonal flu vaccination. Thus, on a population level, this cross-protective immunity may explain the unexpectedly slow unfolding of the pandemic in Sweden despite the absence of a lock-down. Whether a person becomes infected will depend on the infectious dose and the level of immunological protection against flu at the time of exposure. 
medRxiv preprint doi: https://doi.org/10.1101/2021.12.23.21268321; this version posted December 25, 2021. The copyright holder for this

\section{Can flu vaccine strategies affect SARS-CoV-2 severity among children?}

Higher numbers of hospitalized children infected with the delta variant have been reported in the US, the UK, and Israel, but not in Sweden. Seasonal flu vaccinations are recommended for children in the US, the UK, and Israel. In Sweden, however, flu vaccinations are recommended only for high-risk groups and for people over 65 years of age. A flu-mediated pre-immunity to SARS-CoV2 may be less efficient and less sustainable after repeated flu vaccinations than after influenza A H1N1 infection that would elicit robust B- and T-cell immunity. The flu vaccination recommendations and favorable HLA types might explain Sweden's lower incidence of severe COVID-19 disease in children under 10 years of age who had swine flu as their first influenza A H1N1 infection. So far, Sweden has not had high rates of severe infections among children requiring hospital care; however, multisystem inflammatory syndrome in children is twice as prevalent in Sweden as in the US. The syndrome develops 4-6 weeks after diagnosis of COVID19 and may not be related to the severity of SARS-CoV-2 infection; it may have another etiology and its incidence may be related to the number of infections. Sweden kept schools open during the pandemic and had high levels of transmission among children, but few became severely ill in the acute phase of COVID-19. Flu vaccination strategies together with unfavorable HLA types with lower capacity to present flu peptides to T cells may explain differences in susceptibility to SARSCoV-2 infection and the risk of developing severe COVID-19 in different parts of the world.

\section{Has flu-mediated immunity selected for current variants of concern?}

New "variants of concern" that are thought to be more contagious have already spread rapidly over the world, and current vaccines may provide less protection against them (36). The gamma (P1, Brazil), alpha (B1.1.7, Britain), and beta (B.1.351, South Africa) strains contain an N501Y mutation that is thought to enhance by 10 -fold the binding affinity of the spike 1 protein for the 
medRxiv preprint doi: https://doi.org/10.1101/2021.12.23.21268321; this version posted December 25, 2021. The copyright holder for this

ACE2 receptor (37-39). The delta strain (B.1.617) has a T478K mutation, and the NY iota strain has a $\mathrm{S} 477 \mathrm{~N}$ mutation in the receptor binding domain, which may also reduce protection from vaccines (40). Interestingly, the N501Y, S477N, and T478K mutations flank the NGVEGF cysteine loop at aa 481 to 486, which interacts with the ACE2 receptor. As a result of these mutations, NGVKGF-specific antibodies may become less protective, enabling these viral strains to infect a higher proportion of individuals at lower doses. It is possible and even highly likely that the N501Y, S477N, and T487K mutations in SARS-CoV-2 evolved through laws of Darwinian evolution to increase affinity for the ACE2 receptor and to evade NGVEGF-interacting antibodies, making these variants more contagious. Thus, the pre-existing flu-mediated immunity may have selected for these variants of concern.

Mutant strains have rapidly outcompeted the original strain. We recently estimated how much pre-existing protective immunity was lost against the alpha strain when it was circulating in Stockholm during the third wave and by mid-April 2021 accounted for $92 \%$ of cases (11). Our modeling data suggest that pre-immunity levels decreased by approximately 10 percentage points, from $62 \%$ for the original strain to $52 \%$ for the alpha strain (11). Thus, the extent to which flumediated pre-immunity protects against the delta strain and future mutants may considerably affect the further development of the pandemic. The delta variant is now the most prevalent strain in Sweden, and omicron is starting to emerge. The levels of SARS-CoV-2-specific antibodies induced by current vaccines and infections seem to decline within 6-10 months. Until recently, the delta variant had not caused a high surge in cases in Sweden as was observed in Israel, the UK, and the US despite their high vaccine coverage. This discrepancy may be explained by our modeling data, which suggest that Stockholm has already reached herd immunity twice $(10,11)$. The question is now how much of this established immunity, which fades rather rapidly for SARS- 
medRxiv preprint doi: https://doi.org/10.1101/2021.12.23.21268321; this version posted December 25, 2021. The copyright holder for this

$\mathrm{CoV}-2$, can protect us against new strains, such as omicron. Omicron has 32 mutations, including critical mutations in the receptor binding domain (S477N, T478K, E484A, Q493R, G496S, Q498R, N501Y, and Y505H). As this region is targeted by flu- and SARS-CoV-2-specific antibodies, these mutations were likely selected to avoid both flu and SARS-CoV-2 immunity; as expected, omicron is highly contagious and is now rapidly spreading over the world, even among vaccinated individuals. We therefore expect a high surge of SARS-CoV-2 cases in Sweden in the coming months, especially if delta and omicron do not outcompete each other and therefore circulate at the same time, causing a major impact on vulnerable individuals and the health care system.

Our modeling data have limitations. First, levels of antibodies against NGVEGF, predicted Tcell responses, and the neutralization assay have no threshold to estimate protection on an individual level and should be considered to be more relevant on a population level. Second, the mathematical model can only suggest a range of pre-immunity levels that are likely to be true in reality. Thus, both SEIR models and the method developed here are crude tools, and the results should be interpreted with caution. However, SIR (susceptible, infective, recovered) and SEIR models that did not include pre-immunity failed to predict the dynamics of SARS-CoV-2 spread. This is the main mathematical argument for the existence of a pre-existing immunity, the exact level of which is hard to estimate with certainty. On the other hand, the estimated pre-immunity levels from SEIR models and the completely different mathematical tool we devised for this study yielded remarkably consistent results, near the levels suggested by pre-immunity data presented here-supporting the existence of flu-mediated antibodies and T cells that cross react with and protect against SARS-CoV-2 infection or from severe COVID-19 in a high proportion of Swedish 
medRxiv preprint doi: https://doi.org/10.1101/2021.12.23.21268321; this version posted December 25, 2021. The copyright holder for this preprint (which was not certified by peer review) is the author/funder, who has granted medRxiv a license to display the preprint in perpetuity. All rights reserved. No reuse allowed without permission.

people. This scenario would also explain why so many people in Sweden were not infected despite household exposure, had asymptomatic infections, or experienced mild disease. However, the situation may now rapidly change, with the emerging omicron strain and other future variants of this virus selected to avoid current immunity pressure.

We conclude that the possible high prevalence of flu-mediated cross-protective immunity to SARS-CoV-2 is of critical importance for understanding SARS-CoV-2 susceptibility, vaccine responses, protection against new variants, the natural course of COVID-19 in different individuals, and the impact of this virus and its mutants on our society.

\section{Ethical approval}

(Dnr 2020-06333: all vaccinated subjects gave written informed consent; blood donors from blood bank were anonymous; Dnr 2020-07232: all subjects gave written informed consent; Dnr 06400: included anonymous blood samples from healthy donors (HD) in 2011 (Dnr: 01-420) and in 1996 (Dnr: 95-397 and 02-091). Ethical approval was obtained for the animal study (Dnr 16.07.2021).

\section{Statistical analysis}

One-way ANOVA and Turkey's multiple comparison test were used for multiple comparisons. Unpaired $t$ tests were used to analyze mean fluorescent intensity (MFI) values for COVID-19positive and COVID-19-negative cohorts. Paired $t$ tests were used to analyze the same cohorts before and after vaccination. All statistical analyses were done with GraphPad Prism 9.

\section{SUPPLEMENTARY MATERIALS}

Materials and Methods

Tables S1 to S4

References (1-9) 


\section{References and Notes}

1. D. L. N. M. Ferguson, G. Nedjati-Gilani, N. Imai, K. Ainslie, M. Baguelin, S. Bhatia, A. Boonyasiri, Z. Cucunubá, G. Cuomo-Dannenburg, A. Dighe, I. Dorigatti, H. Fu, K. Gaythorpe, W. Green, A. Hamlet, W. Hinsley, L. C. Okell, S. van Elsland, H. Thompson, R. Verity, E. Volz, H. Wang, Y. Wang, P. G.T. Walker, C. Walters, P. Winskill, C. Whittaker, C. A Donnelly, S. Riley, A. C. Ghani., Report 9: Impact of nonpharmaceutical interventions (NPIs) to reduce COVID-19 mortality and healthcare demand. Imperial College London, 10(77482), 491-497 (2020).

2. C. Huang et al., Clinical features of patients infected with 2019 novel coronavirus in Wuhan, China. Lancet 395, 497-506 (2020).

3. F. Zhou et al., Clinical course and risk factors for mortality of adult inpatients with COVID-19 in Wuhan, China: a retrospective cohort study. Lancet 395, 1054-1062 (2020).

4. M. O'Driscoll et al., Age-specific mortality and immunity patterns of SARS-CoV-2. Nature, (2020).

5. L. F. Moriarty et al., Public Health Responses to COVID-19 Outbreaks on Cruise Ships - Worldwide, February-March 2020. MMWR Morb Mortal Wkly Rep 69, 347-352 (2020).

6. A. S. Rudberg et al., SARS-CoV-2 exposure, symptoms and seroprevalence in healthcare workers in Sweden. Nat Commun 11, 5064 (2020).

7. Z. J. Madewell, Y. Yang, I. M. Longini, Jr., M. E. Halloran, N. E. Dean, Household Transmission of SARS-CoV-2: A Systematic Review and Meta-analysis. JAMA Netw Open 3, e2031756 (2020).

8. J. F. Lindahl et al., High seroprevalence of SARS-CoV-2 in elderly care employees in Sweden. Infect Ecol Epidemiol 10, 1789036 (2020).

9. P. Pathela et al., Seroprevalence of Severe Acute Respiratory Syndrome Coronavirus 2 Following the Largest Initial Epidemic Wave in the United States: Findings From New York City, 13 May to 21 July 2020. J Infect Dis 224, 196-206 (2021).

10. M. Carlsson, G. Hatem, C. Söderberg-Nauclér, Mathematical modeling suggests pre-existing immunity to SARS-CoV-2. MedRxiv, (2021).

11. M. Carlsson, C. Söderberg-Nauclér, Pre-immunity to influenza A H1N1 affects COVID-19 outbreak dynamics, predicts herd immunity thresholds, and implies that Stockholm has reached herd immunity twice. MedRxiv, (2021).

12. A. Grifoni et al., Targets of T Cell Responses to SARS-CoV-2 Coronavirus in Humans with COVID-19 Disease and Unexposed Individuals. Cell 181, 1489-1501 e1415 (2020).

13. J. Braun et al., SARS-CoV-2-reactive T cells in healthy donors and patients with COVID-19. Nature 587, 270-274 (2020).

14. N. Le Bert et al., SARS-CoV-2-specific T cell immunity in cases of COVID-19 and SARS, and uninfected controls. Nature 584, 457-462 (2020).

15. L. Swadling et al., Pre-existing polymerase-specific T cells expand in abortive seronegative SARS-CoV-2. Nature, (2021). 
medRxiv preprint doi: https://doi.org/10.1101/2021.12.23.21268321; this version posted December 25, 2021. The copyright holder for this preprint (which was not certified by peer review) is the author/funder, who has granted medRxiv a license to display the preprint in perpetuity. All rights reserved. No reuse allowed without permission.

16. Z. Ma, P. Li, A. Ikram, Q. Pan, Does Cross-neutralization of SARS-CoV-2 Only Relate to High Pathogenic Coronaviruses? Trends Immunol 41, 851-853 (2020).

17. S. Jiang, L. Du, Effect of Low-Pathogenic Human Coronavirus-Specific Antibodies on SARS-CoV-2. Trends Immunol 41, 853-854 (2020).

21. M. Lipsitch, Y. H. Grad, A. Sette, S. Crotty, Cross-reactive memory T cells and herd immunity to SARSCoV-2. Nat Rev Immunol 20, 709-713 (2020).

22. T. Greenhalgh et al., Ten scientific reasons in support of airborne transmission of SARS-CoV-2. Lancet 397, 1603-1605 (2021).

23. F. Bertoglio et al., SARS-CoV-2 neutralizing human recombinant antibodies selected from pre-pandemic healthy donors binding at RBD-ACE2 interface. Nat Commun 12, 1577 (2021).

24. E. M. Anderson et al., Seasonal human coronavirus antibodies are boosted upon SARS-CoV-2 infection but not associated with protection. Cell 184, 1858-1864 e1810 (2021).

25. J. Yang et al., Molecular interaction and inhibition of SARS-CoV-2 binding to the ACE2 receptor. Nat Commun 11, 4541 (2020).

26. W. C. Liu, C. Y. Lin, Y. T. Tsou, J. T. Jan, S. C. Wu, Cross-Reactive Neuraminidase-Inhibiting Antibodies Elicited by Immunization with Recombinant Neuraminidase Proteins of H5N1 and Pandemic H1N1 Influenza A Viruses. J Virol 89, 7224-7234 (2015).

27. X. Xie et al., Neutralization of SARS-CoV-2 spike $69 / 70$ deletion, E484K and N501Y variants by BNT162b2 vaccine-elicited sera. Nat Med 27, 620-621 (2021).

28. M. Verghese et al., A SARS-CoV-2 Variant with L452R and E484Q Neutralization Resistance Mutations. J Clin Microbiol 59, e0074121 (2021).

29. S. Hober et al., Systematic evaluation of SARS-CoV-2 antigens enables a highly specific and sensitive multiplex serological COVID-19 assay. Clin Transl Immunology 10, e1312 (2021).

30. D. Marin-Hernandez, R. E. Schwartz, D. F. Nixon, Epidemiological evidence for association between higher influenza vaccine uptake in the elderly and lower COVID-19 deaths in Italy. J Med Virol 93, 64-65 (2021).

31. G. Fink et al., Inactivated trivalent influenza vaccination is associated with lower mortality among patients with COVID-19 in Brazil. BMJ Evid Based Med, (2020).

32. A. Conlon, C. Ashur, L. Washer, K. A. Eagle, M. A. Hofmann Bowman, Impact of the influenza vaccine on COVID-19 infection rates and severity. Am J Infect Control 49, 694-700 (2021).

33. P. A. Debisarun et al., Induction of trained immunity by influenza vaccination - impact on COVID-19.

PLoS Pathog 17, e1009928 (2021). 
medRxiv preprint doi: https://doi.org/10.1101/2021.12.23.21268321; this version posted December 25, 2021. The copyright holder for this preprint (which was not certified by peer review) is the author/funder, who has granted medRxiv a license to display the preprint in perpetuity. All rights reserved. No reuse allowed without permission.

36. C. Rees-Spear et al., The effect of spike mutations on SARS-CoV-2 neutralization. Cell Rep 34, 108890 (2021).

37. C. Graham et al., Impact of the B.1.1.7 variant on neutralizing monoclonal antibodies recognizing diverse epitopes on SARS-CoV-2 Spike. bioRxiv, (2021).

38. Y. Liu et al., The N501Y spike substitution enhances SARS-CoV-2 infection and transmission. Nature, (2021).

39. A. Khan et al., Preliminary Structural Data Revealed That the SARS-CoV-2 B.1.617 Variant's RBD Binds to ACE2 Receptor Stronger Than the Wild Type to Enhance the Infectivity. Chembiochem 22, 2641-2649 (2021).

40. R. Wang, J. Chen, K. Gao, G. W. Wei, Vaccine-escape and fast-growing mutations in the United Kingdom, the United States, Singapore, Spain, India, and other COVID-19-devastated countries. Genomics 113, 2158-2170 (2021).

\section{Acknowledgments:}

We thank the SciLifeLab Autoimmunity and Serology Profiling infrastructure unit for multiplex bead array serology and Cecilia Hellström, Peter Nilsson and Sophia Hober for their valuable input. We thank Benjamin Murrell and Daniel Scheward for performing an initial pseudo neutralization assay for the project and for their valuable input in discussions of our data. We thank Jonna Hermansson and Lisa Lindberg for their help with sample collection at the elderly care home, Koon Chu Yaiw for sample preparations, Angela Silveira for providing the cohort of blood samples from 1996 and all individuals who donated blood to this study. Finally, we thank Stephen Ordway for excellent help with editing the manuscript.

Funding: This research was partially funded by the Swedish Research Council (VR: 201901736, 2017-05807, 2018-02569), The European Union's Horizon 2020 Research Innovation 
medRxiv preprint doi: https://doi.org/10.1101/2021.12.23.21268321; this version posted December 25, 2021. The copyright holder for this preprint (which was not certified by peer review) is the author/funder, who has granted medRxiv a license to display the preprint in perpetuity. All rights reserved. No reuse allowed without permission.

Program under grant 874735 (VEO), The Knut and Alice Wallenberg Foundation, and the

Science for Life Laboratory Uppsala (Projects: Nevermore Covid, SiCoV and Molres).

\section{Author contributions:}

Conceptualization: CSN, PR, AS, MO, BS, CM, NMA. Methodology: CSN, AR, BR, PR, AS, SA,

ÅL, TH, MO, BS, CM, MC, LK, NMA. Software: MC. Visualization: AR, PR, AN, NMA. Validation: CSN, AR, BR, PR, ÅL, TH, LK, NMA. Formal analysis: CSN, AR, BR, PR, AN, MC. Investigation: AR, BR, PR, ILF, MRP, SA, ÅL, TH, MS, LK, NMA. Resources: PR, ILF, MRP, SA, ÅL, CM. Data Curation: AR, TH, AN, LK, NMA. Funding acquisition: CSN, ÅL. Project administration: CSN, AR, PR. Supervision: CSN, PR, ÅL. Writing - original draft: CSN. Writing - review \& editing: CSN, AR, BR, PR, ILF, MRP, AS, SA, AN, MS, ÅL, TH, MO, BS, CM, MC, LK, NMA

Competing interests: BS, AS have submitted a patent application for a Covid-19 peptide vaccine. Other authors declare that they have no competing interests.

Data and materials availability: All data are available in the main text or the supplementary materials. 


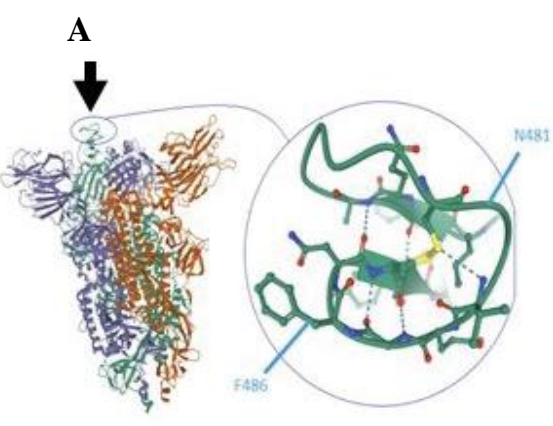

B
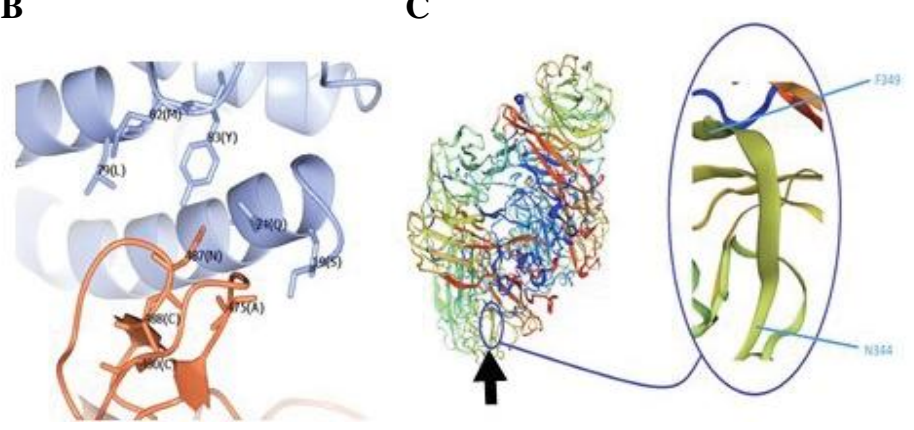

D
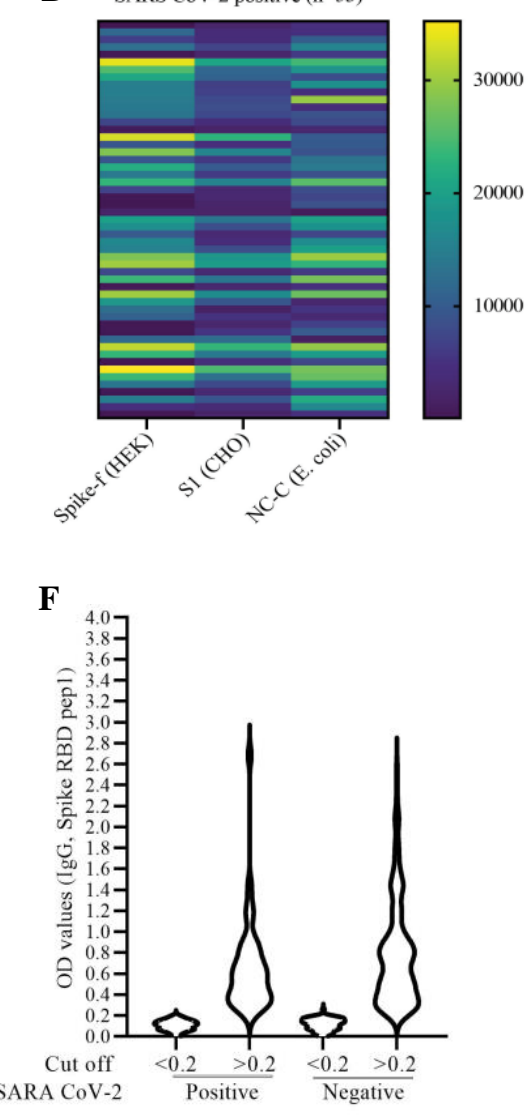

H

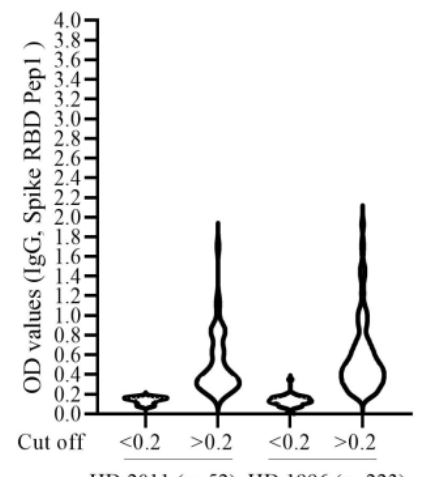

HD 2011 (n=52) HD $1996(\mathrm{n}=223)$
$\mathbf{E}$

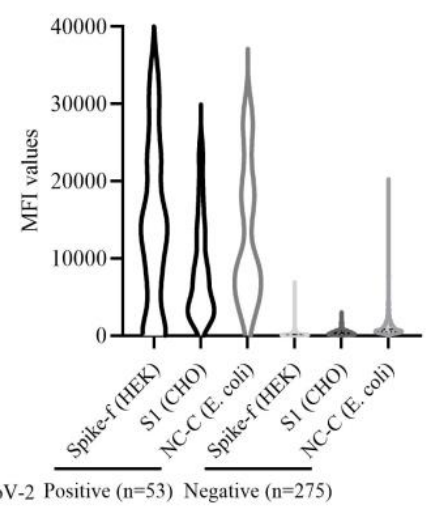

G

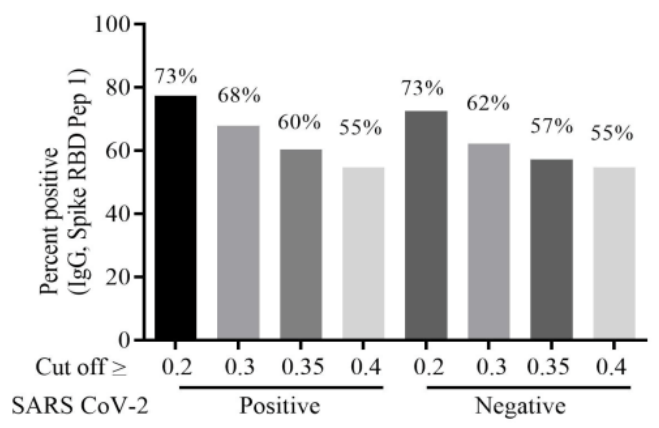

I

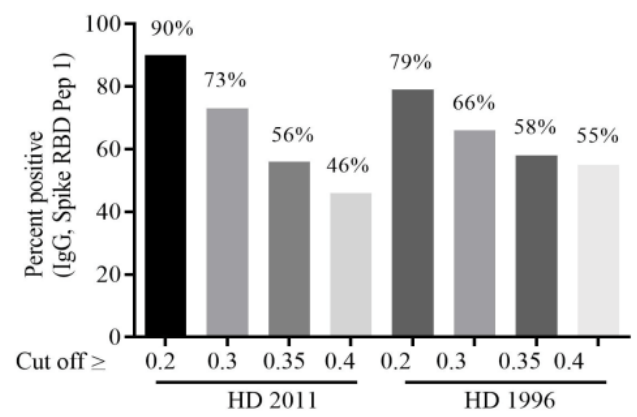


medRxiv preprint doi: https://doi.org/10.1101/2021.12.23.21268321; this version posted December 25, 2021. The copyright holder for this preprint (which was not certified by peer review) is the author/funder, who has granted medRxiv a license to display the preprint in perpetuity. All rights reserved. No reuse allowed without permission.

Fig. 1. (A) Localization of the NGVEGF peptide in the spike protein of SARS-CoV-2. (B) NGVEGF is present in the critical domain of SARS-CoV-2 that interacts with the ACE2 receptor. (C) NGVKGF is situated in a highly immunodominant region of the neuraminidase enzyme of influenza A H1N1 and is expected to elicit an antibody response in most people infected with influenza A H1N1. (D and E) Fifty-three of 328 subjects had IgG antibodies (mean MFI >6 SD) against soluble pre-fusion stabilized trimeric spike glycoprotein (SPIKE-f (HEK)). (F) NGVEGF-specific IgG antibody levels in COVID-19-positive and COVID-19-negative subjects, measured by ELISA. (G) Prevalence of NGVEGF-specific IgG antibody values (cut-off values are shown for OD >0.2, >0.3, >0.35, and >0.4) in COVID-19-positive and COVID-19negative subjects. (H) NGVEGF-specific IgG antibody levels in serum samples from healthy donors in 2001 and 1996, measured by ELISA. (I) Prevalence of NGVEGF-specific IgG antibody values (cut-off values are shown for $\mathrm{OD}>0.2,>0.3,>0.35$, and $>0.4$ ) in healthy donors from 2011 and 1996. 
medRxiv preprint doi: https://doi.org/10.1101/2021.12.23.21268321; this version posted December 25, 2021. The copyright holder for this preprint (which was not certified by peer review) is the author/funder, who has granted medRxiv a license to display the preprint in perpetuity. All rights reserved. No reuse allowed without permission.

A

SARS CoV-2 positive individuals ( $\mathrm{n}=53$ )

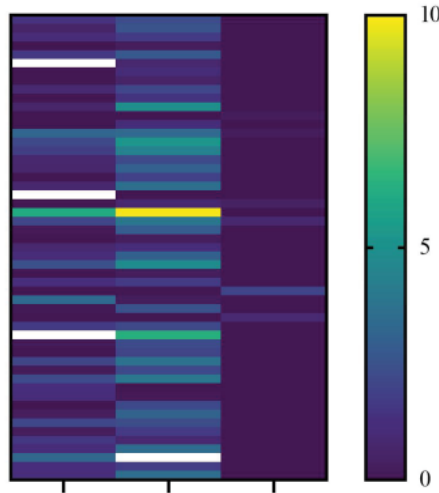

Peptide 3 Peptide 7 Peptide 11

SPIKE RBD

MAD Values

SARS CoV-2 negative individuals ( $\mathrm{n}=275$ )

C

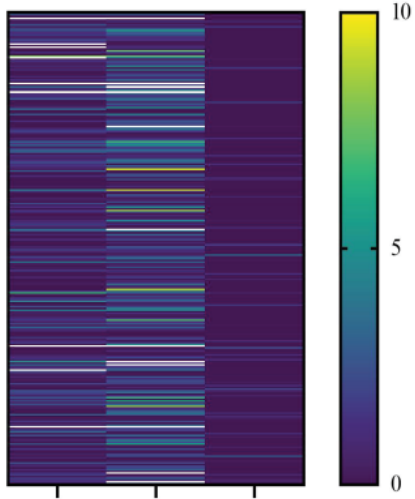

Peptide 3 Peptide 7 Peptide 11

SPIKE RBD

E

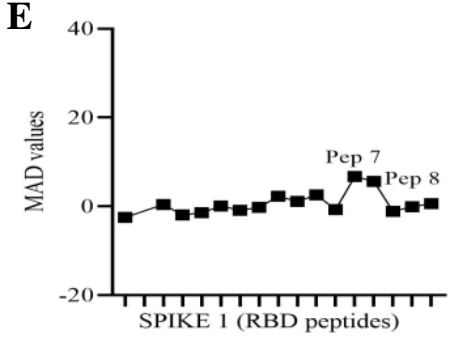

G

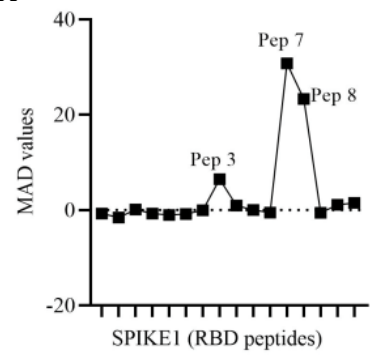

B

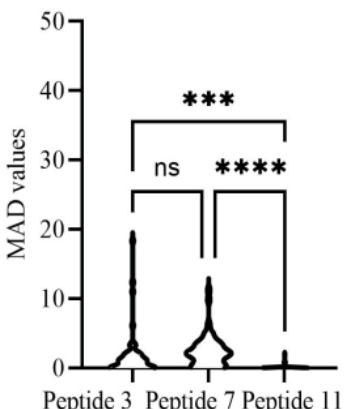

SPIKE RBD
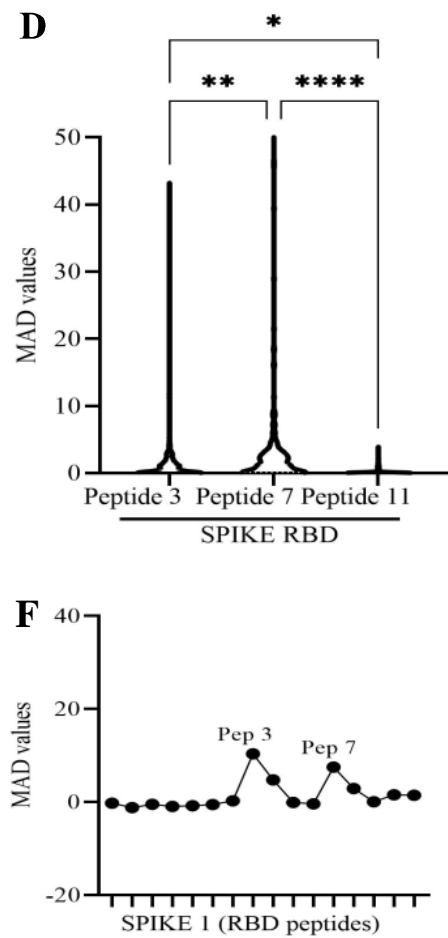

H

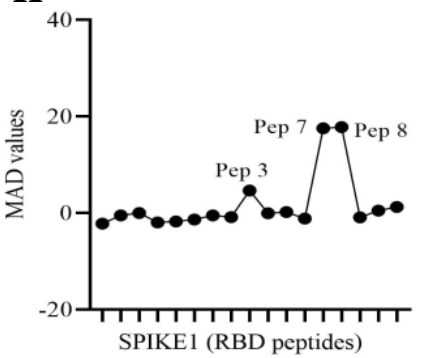


medRxiv preprint doi: https://doi.org/10.1101/2021.12.23.21268321; this version posted December 25, 2021. The copyright holder for this preprint (which was not certified by peer review) is the author/funder, who has granted medRxiv a license to display the preprint in perpetuity. All rights reserved. No reuse allowed without permission.

Fig. 2. Heat map showing peptide-specific IgG antibodies and bead array assay data (MAD) in COVID-19-positive and COVID-19-negative individuals. (A and C) Heat map of MAD values for peptides 3, 7, and 11 in COVID-19 positive (A) and COVID-19-negative (C) cohorts. (B and D) The IgG antibody levels (MAD values) to the NGVKGF (peptide 7) were higher than to the NGVEGF peptide (peptide 3) in both COVID-19-positive (B) and COVID-19-negative (D) cohorts. (E-H) Peptide-specific IgG antibodies in two COVID-19-positive individuals (E and F), in a subject who was exposed to Flu and SARS CoV-2 but did not get sick (G), and in an COVID-19-negative subject (H). ****p $<0.00001, * * * \mathrm{p}<0.0001, * * \mathrm{p}<0.001, * \mathrm{p}<0.01$, ns: no significant. 
medRxiv preprint doi: https://doi.org/10.1101/2021.12.23.21268321; this version posted December 25, 2021. The copyright holder for this preprint (which was not certified by peer review) is the author/funder, who has granted medRxiv a license to display the preprint in perpetuity. All rights reserved. No reuse allowed without permission.

A

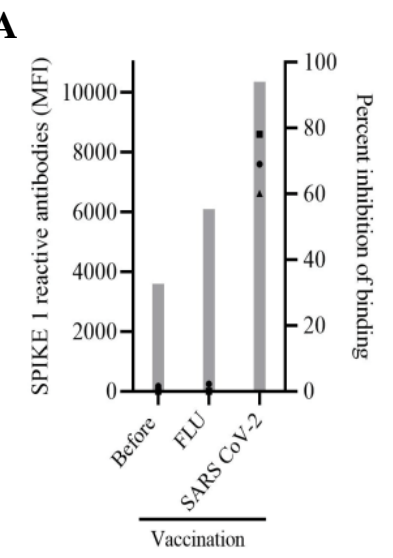

B

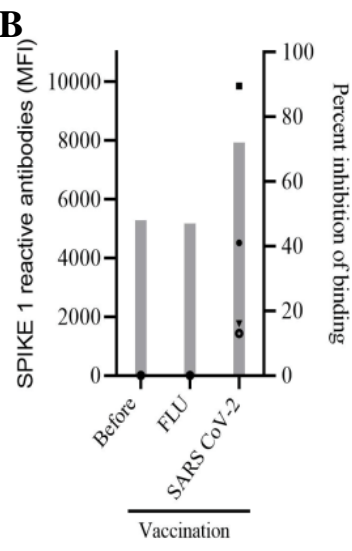

C

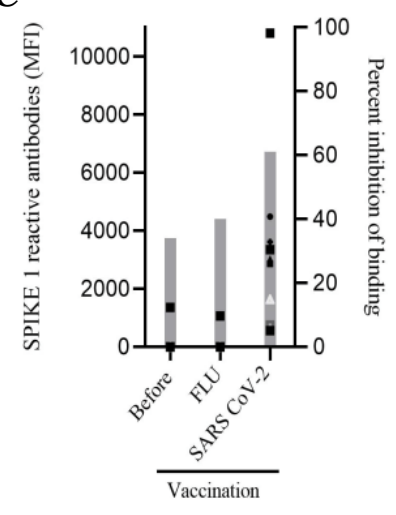

D

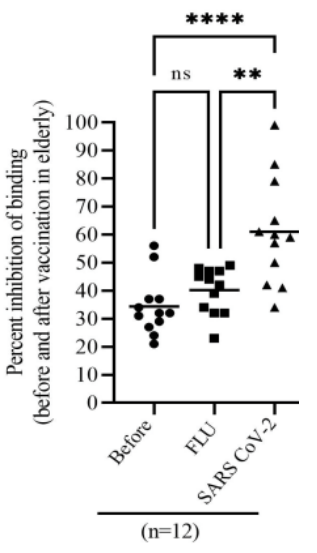

$\mathbf{E}$

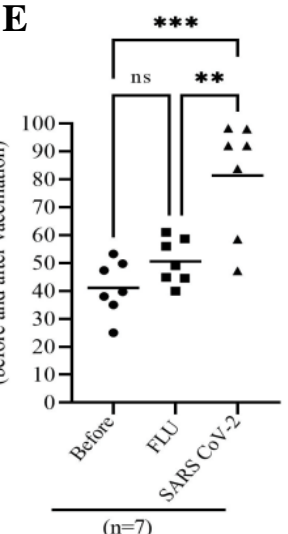

$* * * *$

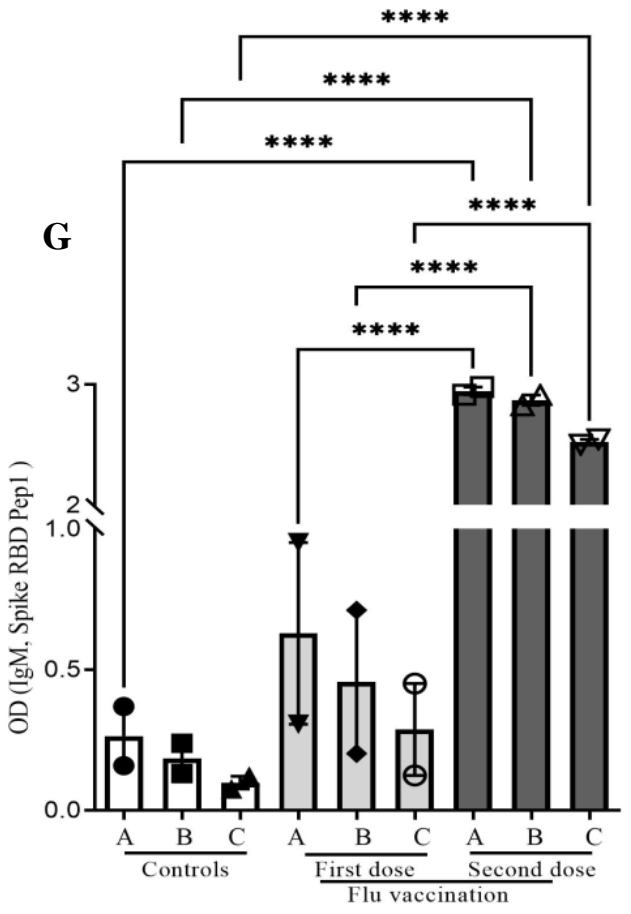

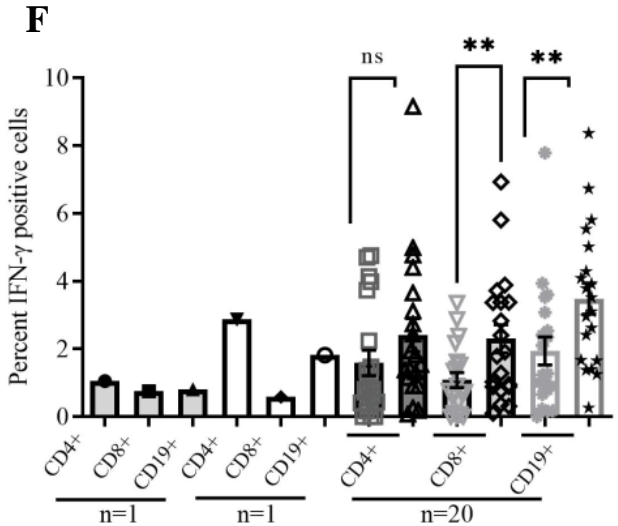

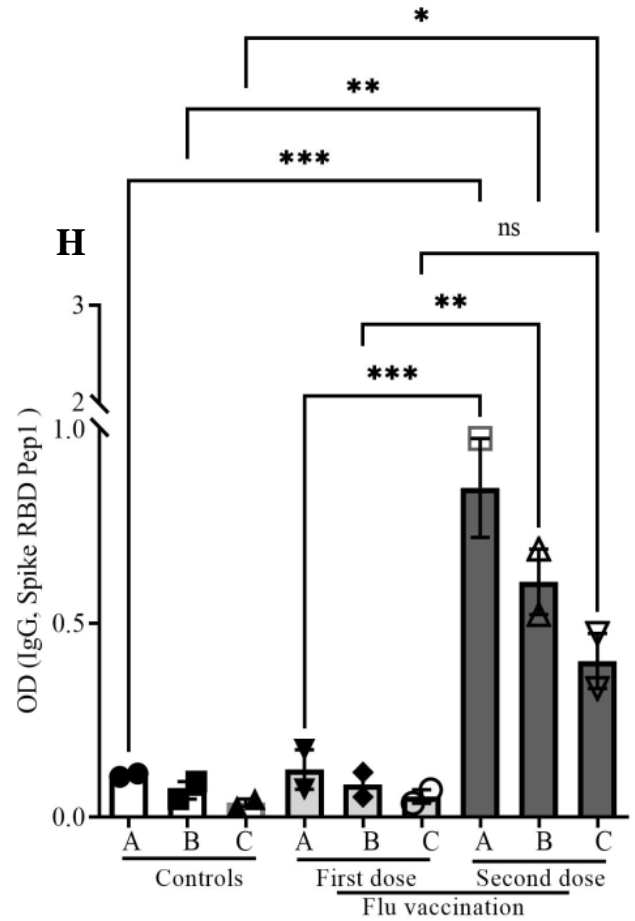


medRxiv preprint doi: https://doi.org/10.1101/2021.12.23.21268321; this version posted December 25, 2021. The copyright holder for this preprint (which was not certified by peer review) is the author/funder, who has granted medRxiv a license to display the preprint in perpetuity. All rights reserved. No reuse allowed without permission.

Fig. 3. Inhibitory activity detected in plasma/serum with a surrogate virus neutralization assay and detection of SARS-CoV-2 spike IgG antibodies. (A-C): Grey bars represent mean value of binding inhibition, individual signs represent MFI value for spike 1 reactive antibodies. (A) Individuals $(n=3)$ with no recent anamnestic flu infection had lower binding inhibitory activity, which was boosted by flu vaccination. (B) Four subjects who had evidence of anamnestic flu had binding inhibitory activity at levels similar to those after flu vaccination; this immunity level was not further enhanced by flu vaccination. (C) In 12 elderly subjects, COVID-19 vaccination increased binding inhibitory activity against SARS-CoV-2 to a mean value of $61 \%$. (D) Increased binding inhibitory activity after SARS-CoV-2 vaccination (mean values: $34.3 \%$ before vaccination, $40.2 \%$ after flu vaccination, and $61 \%$ after SARS CoV-2 vaccination) (E) and in healthy donors below 80 years (mean values: $41.2 \%$ before vaccination, $50.6 \%$ after flu vaccination, and $81.4 \%$ after SARS-CoV-2 vaccination). (F) Increased number of IFN- $\gamma-$ producing B and T cells stimulated with NGVEGF peptides and analyzed by flow cytometry in a group of 20 subjects before and after seasonal flu vaccination (CD4, CD8, and CD19 cells). (G and $\mathrm{H}$ ) Mice received one dose of VaxigripTetra Quadrivalent vaccine (Sanofi Pasteur) followed 2 weeks later by a booster containing the same vaccine and 5 SARS-CoV-2 peptides (table S1). Sera were collected at 2 weeks (response after first dose) and at 6 weeks (response after second dose) and were analyzed for $\operatorname{IgM}(\mathrm{G})$ and $\operatorname{IgG}(\mathrm{H}) * * * * \mathrm{p}<0.00001, * * * \mathrm{p}<0.0001, * * \mathrm{p}<0.001$, $* \mathrm{p}<0.01$, ns: no significant. 
medRxiv preprint doi: https://doi.org/10.1101/2021.12.23.21268321; this version posted December 25, 2021. The copyright holder for this preprint (which was not certified by peer review) is the author/funder, who has granted medRxiv a license to display the preprint in perpetuity.

All rights reserved. No reuse allowed without permission.

A

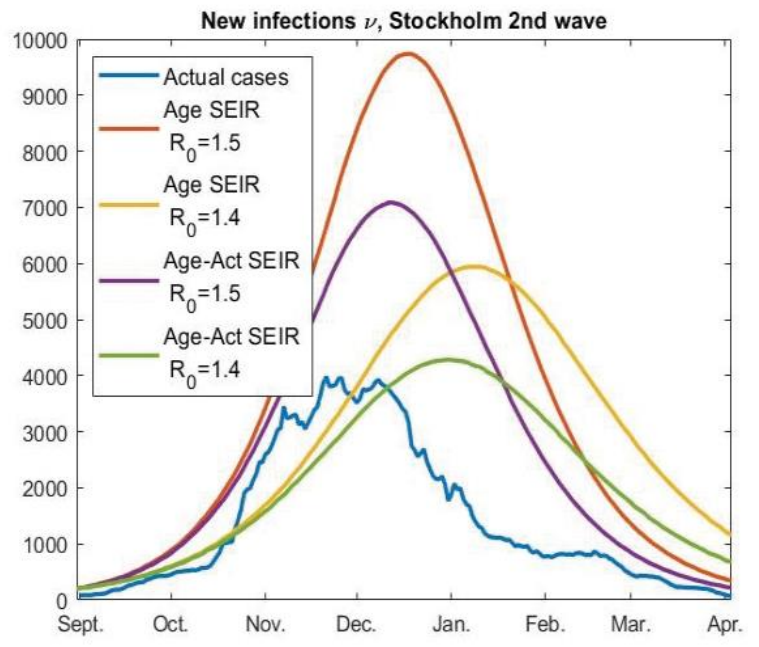

B

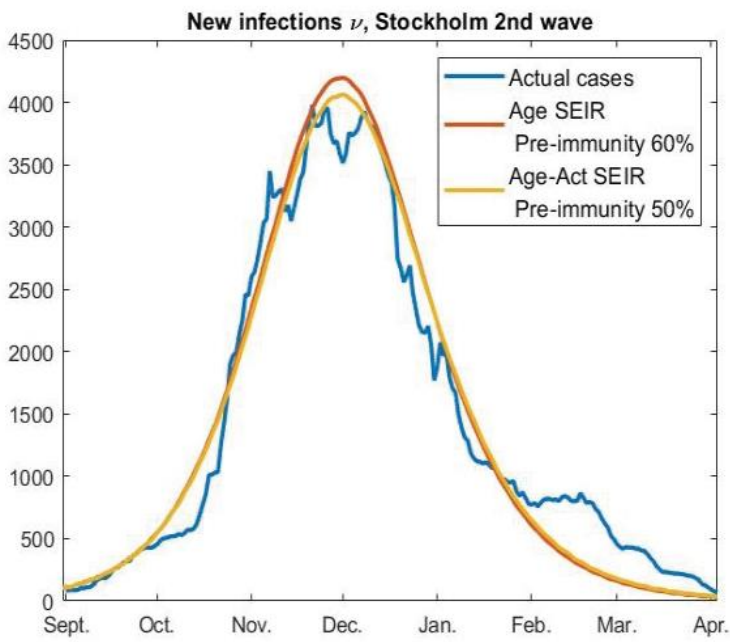

C

Daily new confirmed COVID-19 cases per million people 7 day rolling averagc. Duc to limited testing, the number of confirmed cases is lower than the truc number of infections.

UNEAR LOG

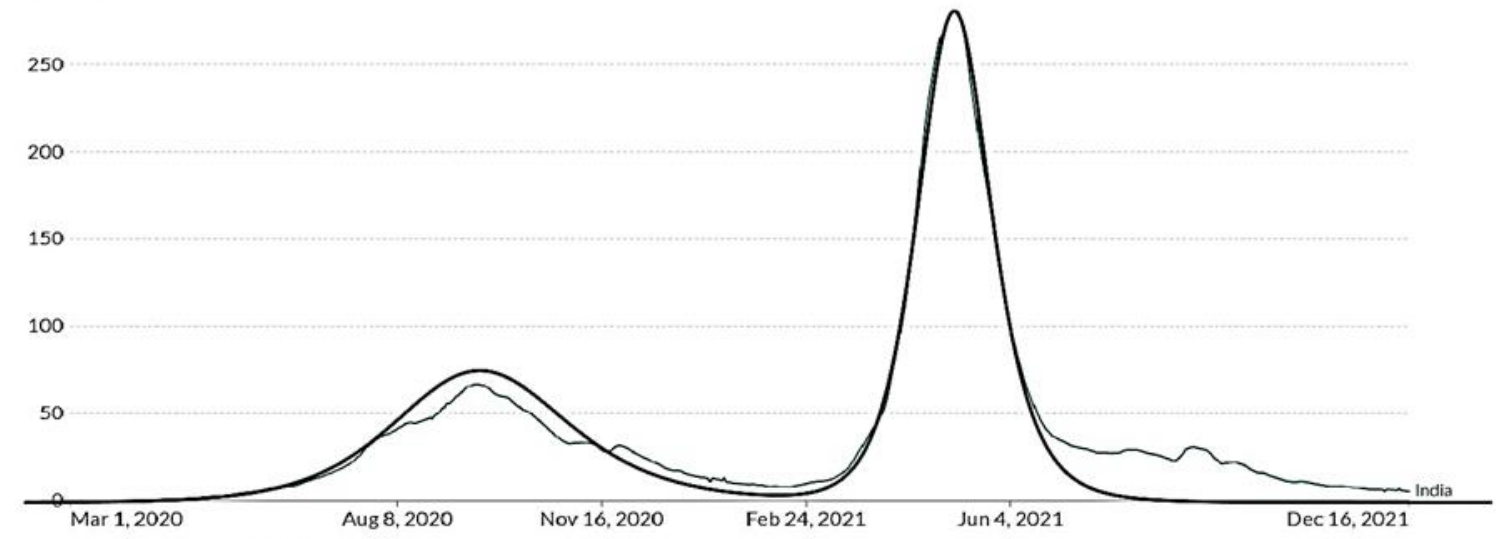

Source: Johns Hopkins University CSSE COVID-19 Data

Mar. Apr. May Jun. Jul. Aug. Sept. Okt. Nov. Dec Jan Feb Mar. Apr. May Jun. Jut. Aug. Sept. Okt. Nov. Dec.

Fig.4. (A and B) Without taking pre-immunity into account, it was not possible to match the development of the second wave in Stockholm County with two heterogeneous SEIR-models developed by Britton et. al.(34): the Age-SEIR model, which takes variable social interactions between different age groups into account, and the Age-Act-SEIR, which also takes variations in 
medRxiv preprint doi: https://doi.org/10.1101/2021.12.23.21268321; this version posted December 25, 2021. The copyright holder for this preprint (which was not certified by peer review) is the author/funder, who has granted medRxiv a license to display the preprint in perpetuity. All rights reserved. No reuse allowed without permission.

social activity within each age group into account. Blue curves are for actual cases. (A) Attempts to fit actual cases in the absence of pre-immunity, using different $\mathrm{R}_{0}$ values. (B) Curves generated with Age-SEIR using 60\% pre-immunity and with Age-Act-SEIR using 50\% preimmunity. (C) The pandemic progression can be accurately modeled for India, using a preimmunity of $25 \%$ against the Wuhan strain and $10 \%$ against the delta variant. 
medRxiv preprint doi: https://doi.org/10.1101/2021.12.23.21268321; this version posted December 25, 2021. The copyright holder for this preprint (which was not certified by peer review) is the author/funder, who has granted medRxiv a license to display the preprint in perpetuity.

All rights reserved. No reuse allowed without permission.

Table 1. H1N1 strains protein sequence for complete neuraminidase.

\begin{tabular}{|l|c|c|c|c|}
\hline H1N1-NA & NGVKGF & NGVEGF & NGIKGF & DGVKGF \\
\hline Before 2008 $(n=1467)$ & $461(31.42 \%)$ & $0(0 \%)$ & $1(<0.01 \%)$ & $990(67.5 \%)$ \\
\hline After 2008 $(n=18972)$ & $18834(99.27 \%)$ & $2(<0.01 \%)$ & $12(<0.01 \%)$ & $107(0.56 \%)$ \\
\hline
\end{tabular}

Data are from fludb.org. 
medRxiv preprint doi: https://doi.org/10.1101/2021.12.23.21268321; this version posted December 25, 2021. The copyright holder for this preprint (which was not certified by peer review) is the author/funder, who has granted medRxiv a license to display the preprint in perpetuity.

\section{References}

1. D. L. N. M. Ferguson, G. Nedjati-Gilani, N. Imai, K. Ainslie, M. Baguelin, S. Bhatia, A. Boonyasiri, Z. Cucunubá, G. Cuomo-Dannenburg, A. Dighe, I. Dorigatti, H. Fu, K. Gaythorpe, W. Green, A. Hamlet, W. Hinsley, L. C. Okell, S. van Elsland, H. Thompson, R. Verity, E. Volz, H. Wang, Y. Wang, P. G.T. Walker, C. Walters, P. Winskill, C. Whittaker, C. A Donnelly, S. Riley, A. C. Ghani., Report 9: Impact of nonpharmaceutical interventions (NPIs) to reduce COVID-19 mortality and healthcare demand. Imperial College London, 10(77482), 491-497 (2020).

2. C. Huang et al., Clinical features of patients infected with 2019 novel coronavirus in Wuhan, China. Lancet 395, 497-506 (2020).

3. F. Zhou et al., Clinical course and risk factors for mortality of adult inpatients with COVID-19 in Wuhan, China: a retrospective cohort study. Lancet 395, 1054-1062 (2020).

4. M. O'Driscoll et al., Age-specific mortality and immunity patterns of SARS-CoV-2. Nature, (2020).

5. L. F. Moriarty et al., Public Health Responses to COVID-19 Outbreaks on Cruise Ships - Worldwide, February-March 2020. MMWR Morb Mortal Wkly Rep 69, 347-352 (2020).

6. A. S. Rudberg et al., SARS-CoV-2 exposure, symptoms and seroprevalence in healthcare workers in Sweden. Nat Commun 11, 5064 (2020).

7. Z. J. Madewell, Y. Yang, I. M. Longini, Jr., M. E. Halloran, N. E. Dean, Household Transmission of SARS-CoV-2: A Systematic Review and Meta-analysis. JAMA Netw Open 3, e2031756 (2020).

8. J. F. Lindahl et al., High seroprevalence of SARS-CoV-2 in elderly care employees in Sweden. Infect Ecol Epidemiol 10, 1789036 (2020).

9. P. Pathela et al., Seroprevalence of Severe Acute Respiratory Syndrome Coronavirus 2 Following the Largest Initial Epidemic Wave in the United States: Findings From New York City, 13 May to 21 July 2020. J Infect Dis 224, 196-206 (2021).

10. M. Carlsson, G. Hatem, C. Söderberg-Nauclér, Mathematical modeling suggests pre-existing immunity to SARS-CoV-2. MedRxiv, (2021).

11. M. Carlsson, C. Söderberg-Nauclér, Pre-immunity to influenza A H1N1 affects COVID-19 outbreak dynamics, predicts herd immunity thresholds, and implies that Stockholm has reached herd immunity twice. MedRxiv, (2021).

12. A. Grifoni et al., Targets of T Cell Responses to SARS-CoV-2 Coronavirus in Humans with COVID-19 Disease and Unexposed Individuals. Cell 181, 1489-1501 e1415 (2020).

13. J. Braun et al., SARS-CoV-2-reactive T cells in healthy donors and patients with COVID-19. Nature 587, 270-274 (2020).

14. N. Le Bert et al., SARS-CoV-2-specific T cell immunity in cases of COVID-19 and SARS, and uninfected controls. Nature 584, 457-462 (2020).

15. L. Swadling et al., Pre-existing polymerase-specific T cells expand in abortive seronegative SARS-CoV-2. Nature, (2021). 
medRxiv preprint doi: https://doi.org/10.1101/2021.12.23.21268321; this version posted December 25, 2021. The copyright holder for this preprint (which was not certified by peer review) is the author/funder, who has granted medRxiv a license to display the preprint in perpetuity. All rights reserved. No reuse allowed without permission.

16. Z. Ma, P. Li, A. Ikram, Q. Pan, Does Cross-neutralization of SARS-CoV-2 Only Relate to High Pathogenic Coronaviruses? Trends Immunol 41, 851-853 (2020).

17. S. Jiang, L. Du, Effect of Low-Pathogenic Human Coronavirus-Specific Antibodies on SARS-CoV-2. Trends Immunol 41, 853-854 (2020).

21. M. Lipsitch, Y. H. Grad, A. Sette, S. Crotty, Cross-reactive memory T cells and herd immunity to SARSCoV-2. Nat Rev Immunol 20, 709-713 (2020).

22. T. Greenhalgh et al., Ten scientific reasons in support of airborne transmission of SARS-CoV-2. Lancet 397, 1603-1605 (2021).

23. F. Bertoglio et al., SARS-CoV-2 neutralizing human recombinant antibodies selected from pre-pandemic healthy donors binding at RBD-ACE2 interface. Nat Commun 12, 1577 (2021).

24. E. M. Anderson et al., Seasonal human coronavirus antibodies are boosted upon SARS-CoV-2 infection but not associated with protection. Cell 184, 1858-1864 e1810 (2021).

25. J. Yang et al., Molecular interaction and inhibition of SARS-CoV-2 binding to the ACE2 receptor. Nat Commun 11, 4541 (2020).

26. W. C. Liu, C. Y. Lin, Y. T. Tsou, J. T. Jan, S. C. Wu, Cross-Reactive Neuraminidase-Inhibiting Antibodies Elicited by Immunization with Recombinant Neuraminidase Proteins of H5N1 and Pandemic H1N1 Influenza A Viruses. J Virol 89, 7224-7234 (2015).

27. X. Xie et al., Neutralization of SARS-CoV-2 spike 69/70 deletion, E484K and N501Y variants by BNT162b2 vaccine-elicited sera. Nat Med 27, 620-621 (2021).

28. M. Verghese et al., A SARS-CoV-2 Variant with L452R and E484Q Neutralization Resistance Mutations. J Clin Microbiol 59, e0074121 (2021).

29. S. Hober et al., Systematic evaluation of SARS-CoV-2 antigens enables a highly specific and sensitive multiplex serological COVID-19 assay. Clin Transl Immunology 10, e1312 (2021).

30. D. Marin-Hernandez, R. E. Schwartz, D. F. Nixon, Epidemiological evidence for association between higher influenza vaccine uptake in the elderly and lower COVID-19 deaths in Italy. J Med Virol 93, 64-65 (2021).

31. G. Fink et al., Inactivated trivalent influenza vaccination is associated with lower mortality among patients with COVID-19 in Brazil. BMJ Evid Based Med, (2020).

32. A. Conlon, C. Ashur, L. Washer, K. A. Eagle, M. A. Hofmann Bowman, Impact of the influenza vaccine on COVID-19 infection rates and severity. Am J Infect Control 49, 694-700 (2021).

33. P. A. Debisarun et al., Induction of trained immunity by influenza vaccination - impact on COVID-19.

PLoS Pathog 17, e1009928 (2021). 
medRxiv preprint doi: https://doi.org/10.1101/2021.12.23.21268321; this version posted December 25, 2021. The copyright holder for this preprint (which was not certified by peer review) is the author/funder, who has granted medRxiv a license to display the preprint in perpetuity. All rights reserved. No reuse allowed without permission.

36. C. Rees-Spear et al., The effect of spike mutations on SARS-CoV-2 neutralization. Cell Rep 34, 108890 (2021).

37. C. Graham et al., Impact of the B.1.1.7 variant on neutralizing monoclonal antibodies recognizing diverse epitopes on SARS-CoV-2 Spike. bioRxiv, (2021).

38. Y. Liu et al., The N501Y spike substitution enhances SARS-CoV-2 infection and transmission. Nature, (2021).

39. A. Khan et al., Preliminary Structural Data Revealed That the SARS-CoV-2 B.1.617 Variant's RBD Binds to ACE2 Receptor Stronger Than the Wild Type to Enhance the Infectivity. Chembiochem 22, 2641-2649 (2021).

40. R. Wang, J. Chen, K. Gao, G. W. Wei, Vaccine-escape and fast-growing mutations in the United Kingdom, the United States, Singapore, Spain, India, and other COVID-19-devastated countries. Genomics 113, 2158-2170 (2021).

41. B. Reynisson, B. Alvarez, S. Paul, B. Peters, M. Nielsen, NetMHCpan-4.1 and NetMHCIIpan-4.0: improved predictions of MHC antigen presentation by concurrent motif deconvolution and integration of MS MHC eluted ligand data. Nucleic Acids Res 48, W449-W454 (2020).

42. B. Ayoglu et al., Anoctamin 2 identified as an autoimmune target in multiple sclerosis. Proc Natl Acad Sci U S A 113, 2188-2193 (2016).

43. Team, R.C.R, A language and environment for stastistical computing. $R$ Foundation for Stastistical Computing, Vienna, Austria, (2019).

44. Team, R. R. Studio, Integrated Development for R. RStudio, Inc., Boston MA, (2018).

45. A. Rahbar et al., Discordant humoral and cellular immune responses to (CMV) in glioblastoma patients whose tumors are positive for CMV. Oncoimmunology 4, e982391 (2015).

46. T. Hoffman et al., Diagnostic Potential of a Luminex-Based Coronavirus Disease 2019 Suspension Immunoassay (COVID-19 SIA) for the Detection of Antibodies against SARS-CoV-2. Viruses 13, (2021).

47. A. Cori, N. M. Ferguson, C. Fraser, S. Cauchemez, A new framework and software to estimate timevarying reproduction numbers during epidemics. Am J Epidemiol 178, 1505-1512 (2013).

48. Q. Bi et al., Epidemiology and transmission of COVID-19 in 391 cases and 1286 of their close contacts in Shenzhen, China: a retrospective cohort study. Lancet Infect Dis 20, 911-919 (2020). 